\title{
The Undergraduate Origins of Ph.D. Economists
}

\author{
by
}

John J. Siegfried and Wendy A. Stock

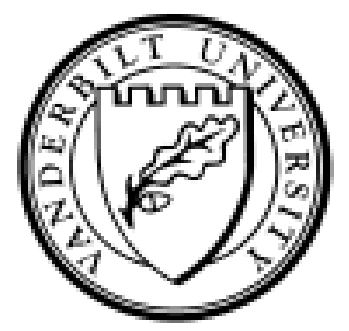

Working Paper No. 06-W11

May 2006

\section{DEPARTMENT OF ECONOMICS \\ VANDERBILT UNIVERSITY \\ NASHVILLE, TN 37235}

www.vanderbilt.edu/econ 


\title{
The Undergraduate Origins of Ph.D. Economists
}

\author{
by $^{*}$ \\ John J. Siegfried \\ and \\ Wendy A. Stock
}

\begin{abstract}
We document the types of undergraduate colleges and universities attended by those who earned a doctorate in economics from an American university from 1966 through 2003 and examine relationships between type of undergraduate institution and attrition and time-to-degree in Ph.D. programs. The total number of new economics Ph.D.s awarded to U.S. citizens has declined precipitously over the past thirty years. Concurrently, the number of economics doctorates who hold undergraduate degrees from U.S. universities has fallen by half: from a high of about 800 in 1972 to about 400 in 2003. Among those who have earned undergraduate degrees from American institutions, the mix of schools attended by the doctorates has remained relatively stable, with about 55 percent of those who earn a Ph.D. in economics each year holding their bachelors degree from a university that offers a Ph.D. in economics, and a bit more than 10 percent holding a bachelors degree from a selective liberal arts college. Currently, 18 of the 25 American undergraduate institutions that send the largest percentage of their graduating classes on to earn a Ph.D. in economics are liberal arts colleges. Graduates of liberal arts colleges also have shorter time-to-degree and higher verbal GRE scores than other economics Ph.D. students.
\end{abstract}

\footnotetext{
* The authors are Professor of Economics at Vanderbilt University and Secretary-Treasurer of the American Economic Association, and Associate Professor of Economics at Montana State University, respectively. The Ford Foundation provided financial support for portions of this research. Lance Selfa at the National Opinion Research Center helped with the acquisition of some of the data. Two anonymous referees, Amanda Bayer, Ronald Ehrenberg, T. Aldrich Finegan, W. Lee Hansen, Hirschel Kasper, and Robert M. Leekley provided helpful comments on an earlier draft.
} 


\section{The Undergraduate Origins of Ph.D. Economists}

The total number of Ph.D.s awarded in economics by U.S. universities has remained between 850 and 1150 per year since 1970. The number of U.S. citizens earning a Ph.D. in economics from an American university, however, has declined steadily for three decades, falling from a peak of 852 in 1973 to a low of 396 in 2003. Moreover, because the fraction of domestic students newly enrolling in economics Ph.D. programs was only about 30 percent in Fall 2002, it will be no surprise if fewer than 300 U.S. citizens earn a Ph.D. in economics from a U.S. university in 2008 and 2009, a level comparable to that last seen during the Eisenhower Administration. In stark contrast, the total number of Ph.D.s awarded by U.S. universities to U.S. citizens and permanent residents across all academic disciplines more than doubled from 1966 to 2000 (Groen and Rizzo, 2004, Table 1), while the number awarded in all of the social sciences (including economics) increased by a factor of 2.5 .

This precipitous decline in both the number and fraction of U.S. economics Ph.D.s earned by U.S. citizens has several implications. First, because only about half of the international students who earn a Ph.D. in economics from an American university remain in the U.S. for their first job, the declining proportion of U.S. citizens among new economics Ph.D.s has steadily reduced the labor supply of Ph.D.s in economics to American colleges, universities, business firms, and government agencies. At the same time, demand for economics Ph.D.s has been growing. New job listings in Job Openings for Economists have increased from 1,613 in 1997 to 2,101 in 2003, while the annual crop of new Ph.D.s produced has declined from about 950 to somewhat under 850. The number of undergraduate students in economics courses has grown over the past thirty years. Annual bachelors degrees awarded in economics increased by 37 
percent from 1972 to $2002 .{ }^{1}$ Because the fraction of new Ph.D. economists entering academe has remained fairly constant, at about 60 percent, during the same period (Siegfried and Stock, 2004), average economics class sizes in U.S. colleges and universities have necessarily been increasing (or taught by non-Ph.D.s). This tightening in the domestic labor market is evidenced by the recent increase in starting salaries, leading to salary compression and, in a few documented cases, salary inversion, so that some first year faculty earn more than sixth year faculty who are above average in productivity and working in the same department (Siegfried and Stock, 2006).

Second, domestic and foreign economics Ph.D. students specialize in different fields. A sample of about 800 economists who earned Ph.D.s in either 1996-97 or 2001-02 (see Siegfried and Stock, 1999 and 2004) reveals many statistically significant differences in the domestic and foreign Ph.D. mix by field. For example, 90 percent of new Ph.D.s in economic history are U.S. citizens, and between 55 and 70 percent of those in agricultural and natural resource economics, labor economics, law and economics, public economics, industrial organization, and health, education and welfare economics are U.S. citizens. In contrast, fewer than 40 percent of those specializing in international economics (24 percent), mathematical and quantitative methods (26 percent), macro and monetary economics (36 percent), and microeconomic theory (36 percent) are U.S. citizens. As the mix of new Ph.D. graduates shifts toward relatively fewer domestic students, the stock of professional economists' skills shifts away from economic history and applied micro policy, and toward international economics, mathematical and quantitative methods, and micro and macro theory, changing the nature of what economists do.

\footnotetext{
${ }^{1}$ U.S. Department of Education, National Center for Education Statistics, Higher Education General Information Survey (HEGIS), "Degrees and Other Formal Awards Conferred" surveys, and Integrated Postsecondary Education Data System (IPEDS), "Completions" surveys, 1986-87 through 1998-99, and Fall 2000 through Fall 2002 surveys. Available at: http://nces.ed.gov/programs/digest/d03/tables/dt296.asp
} 
Third, current trends indicate that reliance on international Ph.D. graduates to fill domestic job openings in the U.S. is risky. First-time international graduate student enrollments declined for three consecutive years after September 11, 2001, and international graduate student applications declined by 33 percent from 2003 to 2005 (Brown and Doulis, 2005). Increased competition for Ph.D. students from universities in Europe, Asia, and Australia accounts for some of the decline in interest by international students. Difficulties securing visas for study in the U.S., and diminished perceptions of the U.S. abroad recently have exacerbated the disappearance of international applicants to Ph.D. programs. Whether international graduates will be available to meet U.S. demand for Ph.D. economists in the future is more problematic today than it seemed in the 1990s.

Numerous decisions affect the number of Ph.D.s graduating in economics annually. Because most Ph.D. economists major in economics as undergraduates (Siegfried and Stock, 2004), students must first be attracted to principles of economics and their interest nurtured sufficiently so that the successful ones choose to major in economics (see Lemke, et al. 2005). It is then necessary to prepare undergraduates for graduate work in economics, encouraging them to take mathematics courses beyond the minimum required in most undergraduate curricula. Graduates must subsequently apply for admission to an economics Ph.D. program, at least one program must admit them, and, to indicate a realistic expectation that they can complete the degree, offer them financial aid. They must then enroll and persist in the program, learn skills that are useful to prospective employers, and complete the Ph.D. degree requirements in a sufficiently short time period to take advantage of career opportunities.

In other papers, we have addressed several steps in this progression. We have examined the exposure of college students to a first course in economics (Siegfried, 2000), trends in the 
number of undergraduate degrees awarded in economics (Siegfried and Round, 2001) the time required to earn an economics Ph.D. (Siegfried and Stock, 2001; Stock and Siegfried, 2006), the job market for new Ph.D.s (Siegfried and Stock 1999, 2001, 2004; Stock and Alston, 2000; and Stock, et al., 2000), and the match between economists' graduate training and their subsequent job requirements (Stock and Hansen, 2004). In other ongoing research we are examining the matriculation and attrition decisions of admitted and enrolled Ph.D. students (Finegan, Stock, and Siegfried, 2006; Stock, Finegan, and Siegfried, 2006). A remaining gap in our research on the overall process centers on the decision of undergraduates to apply for admission to a graduate program in economics. Part of this decision necessarily depends on the characteristics of their undergraduate education. Accordingly, this paper presents information on the characteristics of the undergraduate institutions of economics Ph.D.s and examines relationships between those characteristics and other factors in the Ph.D. production process, including attrition and time-todegree.

\section{Undergraduate Origins of Economics Ph.D.s}

In Figure 1, the number of economics Ph.D. degrees awarded by U.S. universities each year to students who earned a bachelor's degree in the U.S. is traced for the period 1966-2003. Because some foreign students earn undergraduate degrees at American colleges and universities and some domestic students earn bachelor's degrees overseas, the pattern in Figure 1 tracks, but is not identical to, the number of Ph.D. degrees awarded to U.S. citizens by U.S. universities each year. ${ }^{2}$ The number of American-undergraduate-institution-trained (AUIT) Ph.D.s peaked at

\footnotetext{
${ }^{2}$ In our sample of 586 students who entered Ph.D. programs in Fall 2002, 36 of 393 foreign students earned their bachelor's degree at a U.S. college, and 6 of 193 Americans earned their bachelor's degree outside the U.S.
} 
close to 800 in the early 1970s, before beginning a steady decline of about one percentage point per year for three decades. ${ }^{3}$

The distribution of types of undergraduate institutions attended by individuals awarded a Ph.D. in economics by American universities each year from 1966 through 2003 is reported in Figure 2. The flat and declining lines in the figure represent four different types of U.S. baccalaureate institutions: those that also offer a Ph.D. in economics; those in U.S. News \& World Report's Top-50 ranked selective private liberal arts colleges in $2004^{4}$, plus Dartmouth, Miami (Ohio), Richmond, Trinity University, Tufts, and William and Mary (which are highly selective institutions that have few graduate programs, but are not classified as private liberal arts colleges); other public institutions; and other private colleges and universities. The increasing line represents economics Ph.D.s awarded to graduates who did not do their undergraduate work in the U.S. The combined AUIT share of Ph.D.s is the reciprocal of the share of those who studied overseas as undergraduates. It declines sharply over time. Because there were about 1,050 Ph.D.s awarded in economics by American universities in both 1972 and 2002, a comparison between those two years is illustrative. The 800 or so AUIT economics Ph.D.s graduating in 1972 comprise about 75 percent of the total number of economics Ph.D. degrees awarded in that year. By 2002, the AUIT share of new Ph.D.s had dropped to slightly below 40 percent, or about 420 Ph.D.s.

\footnotetext{
3 The data in Figure 1 are assembled from the Survey of Earned Doctorates (SED) and Doctorate Records File (DRF), collected on behalf of the National Science Foundation (see webCASPAR.nsf.gov). These surveys have very high response rates and can be considered as comprehensive.

${ }^{4}$ Source: http://www.usnews.com/usnews/edu/college/rankings/ranklibartco_brief.php. The colleges are Amherst, Barnard, Bates, Bard, Bowdoin, Bryn Mawr, Bucknell, Carleton, Centre, Claremont McKenna, Colby, Colgate, Colorado College, Connecticut College, Denison, DePauw, Dickinson, Davidson, Franklin and Marshall, Furman, Gettysburg, Grinnell, Hamilton, Harvey Mudd, Haverford, Holy Cross, Kenyon, Lafayette, Macalester, Middlebury, Mount Holyoke, Oberlin, Occidental, Pomona, Rhodes, Sarah Lawrence, Scripps, Sewanee University of the South, Skidmore, Smith, Swarthmore, Trinity College, Union, Vassar, Wabash, Washington and Lee, Wellesley, Wesleyan, Whitman, and Williams.
} 
The shares of AUIT (not total) Ph.D.s accounted for by each of the four domestic subcategories are shown by decade in Table 1 . They are relatively constant over time, a pattern similar to that observed in science and engineering more generally (Freeman, et al, 2004, Table 3). The only noticeable shift has been a moderate increase in the share of new Ph.D. economists coming from selective private liberal arts colleges. Almost 70 percent of AUIT economics Ph.D.s is accounted for by a combination of the roughly 120 universities that offer a Ph.D. in economics and the Top-50 liberal arts colleges. Together this group of institutions accounts for less than 12 percent of the nation's four-year colleges and universities, but about 69 percent of all undergraduate degrees earned. Not surprisingly, the dominance of higher quality undergraduate institutions in producing future Ph.D.s is not limited to economics but also occurs in most other disciplines (Zhang 2004, p. 17).

Figures 1 through 5 also illustrate other changes in the pattern of U.S. undergraduate alma maters of new American economics doctorates over the past 36 years. As shown in the bottom line of Figure 1, the number of different undergraduate institutions generating each new AUIT Ph.D. cohort has declined by 30 percent, from about 320 institutions during the mid-1970s to 220 institutions in 2003. As Figure 3 illustrates, the typical number of new AUIT Ph.D.s generated per undergraduate institution has declined from about 2.5 in 1972 to less than 1.8 in 2003.

Figure 4 illustrates 3-year moving averages of the share of AUIT Ph.D.s accounted for by the ten undergraduate alma maters generating the most new economics Ph.D.s in each year. This average share declined from a high of 20 percent during the early 1970s, was fairly flat at about 16 percent during the 1980s, and has since risen back to about 18 percent. The 3-year moving average share of AUIT Ph.D.s accounted for by a fixed set of 20 historically elite colleges and 
universities (defined as the eight Ivy League universities, plus Amherst, Chicago, Colgate, Grinnell, Haverford, Oberlin, Stanford, Swarthmore, Vassar, Wellesley, Wesleyan, and Williams ${ }^{5}$ ) has risen from about 14 percent in the 1970s to 18 percent in 2003.

Figure 5 tracks 3-year moving averages of the share of new economics Ph.D.s whose undergraduate study was completed at a set of 20 predominantly engineering colleges. ${ }^{6}$ Both the number and share of Ph.D.s who attended these engineering schools as undergraduates peaked during the 1970s, a reasonable time-to-degree lag from the undergraduate science and engineering enrollment peak stimulated during the post-Sputnik era by the National Defense Education Act. The number of former students at engineering schools who turned into economists declined markedly after 1980, falling from a range of 30-50 per year in the 1970 s to a range of 15-25 in the 1980s. It has since recovered, with these schools generating about 5 percent of AUIT economics Ph.D.s in 2003.

In general, there has been relatively little change in the identity of the undergraduate alma maters of new AUIT Ph.D.s in economics since the Vietnam War. Because of the sharp decline in the total number of AUIT economics Ph.D.s, however, the absolute number of new economics Ph.D.s coming from each category of undergraduate institution has declined substantially. The share of new AUIT economics Ph.D.s who graduated from an elite liberal arts college has

\footnotetext{
${ }^{5}$ The set of "Elite-20" institutions contains ten universities and ten liberal arts colleges. Among the ten universities are the eight northeastern Ivy League universities, Chicago, and Stanford. Seven of the ten were founded before the Revolutionary War. Among the others, Cornell (1865) is part of the Ivy League, and Chicago (1891) and Stanford (1891) are venerable institutions from beyond the northeast. All ten are among U.S. News \& World Report's top 15 ranked national universities. In light of age, location, and academic credentials, only Duke, MIT, and Northwestern might have substituted for one of the ten chosen universities. All ten of the liberal arts colleges were founded before 1870. Eight of the ten are in the northeast. Oberlin (Ohio) and Grinnell (Iowa) were added for geographical diversity. Nine of the ten colleges are among U.S. News \& World Report's top 15 ranked liberal arts colleges. (Oberlin ranked below 15.) In terms of age, location, and academic credentials, only Bowdoin, Carleton, Middlebury, and Davidson might have substituted for one of the ten chosen liberal arts colleges.

${ }^{6}$ The engineering colleges are Cal Poly-San Luis Obispo, Cal Tech, Carnegie Mellon, Case Western Reserve, Cooper Union, Georgia Tech, Harvey Mudd College, Illinois Tech, Michigan Tech, MIT, Purdue University, Rensselaer, Rice, Rose Institute of Technology, Stevens Institute of Technology, Texas A\&M, U.S. Air Force, Military, or Naval Academies, and Virginia Tech.
} 
increased only because their absolute number has declined relatively slower than the other three categories.

The 25 worldwide undergraduate alma maters that generated the most U.S. economics Ph.D.s during 1997-2002 are reported in Table $2^{7}$. The relative importance of several foreign universities that award undergraduate degrees to individuals who eventually earn an economics Ph.D. in the U.S. is obvious. Worldwide, Seoul National University in Korea not only tops Harvard as the leading incubator of future U.S. economics Ph.D.s, but does so by a factor of more than two. During 1997-2002, six of the top ten undergraduate alma maters of new U.S.trained Ph.D. economists were foreign universities—-two from South Korea, and one each from China, India, Italy, and Taiwan. On average, 27 bachelor's graduates of Seoul National University earn a Ph.D. in economics from a U.S university each year, along with seven from Yonsei University and six from Korea University, both also located in Seoul. Based on a dropout rate of 18.5 percent after two years of the Seoul National, Yonsei, and Korea University graduates who entered one of 27 American Ph.D. programs in Fall 2002 and assuming no further attrition among the group, an average annual graduating Ph.D. class of 40 Seoul National, Yonsei, and Korea University alumni implies that at least 50 of their alumni enter U.S. economics Ph.D. programs each year.

The 25 American undergraduate alma maters that generated the most AUIT economics Ph.D.s between 1997 and 2003 are reported in Table 3. The list obviously is dominated by research universities that offer a Ph.D. in economics. Average annual rates of AUIT Ph.D.s generated by these institutions (one-seventh the numbers reported in Table 3) are, for example,

\footnotetext{
${ }^{7}$ These data are not directly available via webCASPAR, but were instead obtained in late 2003 via a special tabulation from the National Opinion Research Center (NORC), the contractor to NSF for the SED. Because NORC continuously updates the webCASPAR data with late arriving surveys and the special tabulation that produced Table 3 occurred about two years before our extraction from webCASPAR of the data used in the rest of this paper, there is a slight difference in the number of Ph.D.s. reported in Tables 2 through 5.
} 
12 from each undergraduate class at Harvard, 10 from each undergraduate class at Berkeley, and about seven annually from Cornell and Stanford. The only real surprises on the list are the private and public liberal arts colleges—e.g., Swarthmore, William and Mary, Williams, and Miami (Ohio) — surrounded by the likes of the larger Universities of Wisconsin, Michigan, Texas, and UCLA. For these highly productive liberal arts colleges, the annual average number of eventual economics Ph.D.s generated ranges from about 5.5 for Swarthmore to 3.5 for Miami (Ohio).

To better illustrate the relative productivity of liberal arts colleges at generating eventual economics Ph.D.s, Table 4 ranks the top 25 institution-size-normalized undergraduate alma maters of economics Ph.D.s. The number of economics Ph.D.s generated by each institution during 1997-2003 is divided by the size of each institution's total undergraduate graduating class from ten years earlier (1987-1993). Although only four liberal arts colleges appear among the top 25 American undergraduate producers of eventual economics Ph.D.s listed in Table 3, Table 4 shows that it is the liberal arts colleges that send the greatest proportion of their graduates on to earn Ph.D.s in economics. Swarthmore leads the list, with an average of one-half of one percent of its graduates each year eventually earning a Ph.D. in economics, or about 15 economics Ph.D.s generated per 1,000 Swarthmore graduates.

Of the top 25 institutions ranked by the proportion of the graduating class that eventually earns a Ph.D. in economics, 24 are private colleges and universities, and the one public institution (College of William and Mary) is the closest thing there is to a liberal arts college in the public sector. Eighteen of the 25 are liberal arts colleges with little or no graduate education on their campus. Although not shown in the table, the trend continues as one moves down these rankings. It is not until we reach rank 54 that a large public university (Berkeley) appears on the 
list! This pattern of dominance of private liberal arts colleges and private universities in producing undergraduates who eventually earn a Ph.D. in economics follows closely the doctoral production pattern in the natural sciences (Tidball 1986, p. 613).

If there are a large number of economics majors at a relatively small institution, even a small proportion of economics majors proceeding on to a Ph.D. can move an institution up the list reported in Table 4. Some economics departments, however, especially those competing with an undergraduate business school, produce a remarkable number of Ph.D. economists from a relatively small pool of economics majors. These institutions are shown in Table 5, where we normalize the eventual economics Ph.D.s generated by each institution by the number of bachelor's degrees it awards in economics. Because of variation in the relative size of economics programs within colleges and universities, only ten of those listed in Table 4 survive among the leading 25 in Table 5. A few colleges and universities with relatively small economics programs near the top of Table 5 are surprising, for example Illinois Wesleyan, the University of Memphis, and Bemidji State.

Finally, to illustrate that the prominence of top liberal arts colleges in generating eventual economics Ph.D.s is not limited to simply the handful of outstanding colleges listed in Tables 4 and 5, Table 6 presents overall institution- and economics-program size-normalized Ph.Ds. generated by each of the four categories of undergraduate institution. Although the economics Ph.D.-granting institutions generated more than 13 times as many BA/BS degrees and more than seven times as many economics BA/BS degrees as the top-50 liberal arts colleges did during 1987-1993, the liberal arts colleges generated about three times as many Ph.D.s per BA/BS awarded and more than twice as many Ph.D.s per economics BA/BS awarded. 
One reason for the disproportionate presence of selective liberal arts college graduates among economics Ph.D.s may be the tendency of individuals to "follow in the footsteps" of their parents (Laband and Lentz, 1985). While fewer than three percent of the nation's college students attend selective liberal arts colleges, almost half of the children of faculty at selective liberal arts colleges, and about a quarter of the children of faculty at national research universities attend selective liberal arts colleges (Siegfried and Getz, 2006, Table 1). With such a hugely disproportionate presence of "faculty brats" at selective liberal arts colleges, only a modest inter-generational correlation in occupation is necessary for liberal arts colleges to be over-represented among Ph.D. students (in any discipline). Furthermore, undergraduate economics students at liberal arts colleges may receive more attention from faculty that leads them to think about a career as a professional economist. The typical (median) economics graduate of a liberal arts college writes almost twice as many economics term papers as does a graduate of a national research university [4.0 vs. 2.2 papers] (McGoldrick, 2006, Table 5b). Moreover, relatively more economics departments in liberal arts colleges than at national universities report that their students' written work is published (65 percent vs. 43 percent), and of that published work, relatively more from liberal arts graduates (77 percent) than from national research university graduates (52 percent) is published in professional academic journals (McGoldrick, 2006, Table 5b). If conducting research that is publishable is more common at liberal arts colleges, academic careers may emanate from liberal arts college graduates more frequently.

The institutions in Table 5 have proven to be very productive at generating eventual economics Ph.D.s - sending between six and 19 percent of their economics graduates on to Ph.D.s. Those institutions among the Top-50 liberal arts colleges or with economics Ph.D. 
programs that send an abnormally low proportion of their economics graduates on to earn Ph.D.s in economics might prove to be fertile ground for recruiting new economics Ph.D. students. These institutions can be identified by reproducing Table 5 absent any limitation on the number of Ph.D.s produced from 1997 to 2003, and looking at the bottom of the list. For example, universities with Ph.D. programs in economics that send less than one-half of one percent of their undergraduate economics graduates on to earn economics Ph.D.s include Connecticut, Fordham, Pittsburgh, SUNY-Albany, SUNY-Buffalo, and Vanderbilt. Top-50 liberal arts colleges that send less than one-half of one percent of their economics graduates on to economics Ph.D.s include Barnard, DePauw, Denison, Hampden-Sydney, Holy Cross, and Union.

\section{Undergraduate Origins and Economics Ph.D. Program Outcomes}

As part of our study of the economics Ph.D. production process, we are following the progress of 586 students who began Ph.D. study in one of 27 economics Ph.D. programs during Fall 2002. Among the 27 are 15 of the 22 largest, and 12 others, each averaging at least 5 Ph.D.s per year. ${ }^{8}$ The programs are diverse in terms of 1993 National Research Council (NRC) ratings (Marvin Goldberger et al., 1995). Three are Tier 1, six Tier 2, seven Tier 3, six Tier 4, and four Tier 5. One is unranked. ${ }^{9}$ Thus, the programs are drawn from all quality tiers; but larger, higherranked universities are over-represented. Together the 27 produced 42 percent of the Ph.D.s issued by U.S. programs awarding at least one degree from 1998 to $2001 .^{10}$ Fourteen of the

\footnotetext{
${ }^{8}$ Each of the 22 programs with the most degrees awarded from 1998 through 2001 was invited to participate; 15 accepted. The remaining 12 programs were selected randomly from the 45 smaller programs that averaged at least 5 Ph.D.s annually from 1998 through 2001.

${ }^{9}$ The first tier of NRC rankings consists of Chicago, Harvard, MIT, Princeton, Stanford, and Yale (three of which are included in our study). The second tier is California-Berkeley, Columbia, Michigan, Minnesota, Northwestern, Pennsylvania, Rochester, UCLA, and Wisconsin. The third tier is programs ranked 16-30; fourth tier programs are ranked 31-48. We included in the fifth tier the remainder of programs, including one not ranked by the NRC.

${ }^{10}$ Based on tabulations from listings in December issues of the Journal of Economic Literature.
} 
largest 20 Ph.D. programs and nine of the top 15 Ph.D. programs in economics as ranked in 1993 by the National Research Council (Goldberger, et al. 1995) are included. ${ }^{11}$

To compare various student characteristics and outcomes across the type of undergraduate institution the Fall 2002 entering cohort of Ph.D. students had attended, we use the same four categories of U.S. colleges and universities employed earlier. However, because of potential differences in language barriers to learning in the U.S., we subdivide the foreign institutions into those in: (a) Britain, Canada, Ireland, Australia, and New Zealand, where English is the dominant language; and (b) all other countries. Using this division, Table 7 shows that 38 percent of the Fall 2002 entering cohort earned a bachelor’s degree from a U.S. college or university, 5 percent from English-language-dominant foreign universities, and 57 percent from other foreign universities.

Assuming that no particular type of undergraduate institution has been more or less successful in luring or pressuring prospective Ph.D. students to apply and enroll if they are admitted, U.S. economics Ph.D. programs that want to boost applications and enrollments from domestically trained undergraduates need not look far. The largest pool of prospects comes from U.S. institutions offering a Ph.D. in economics; close to two-thirds of the AUIT first year students (142/223) earned their undergraduate degrees from these schools. An additional 15 percent of AUIT students are located at the 50 or so most prestigious liberal arts colleges.

Column 3 indicates that by the beginning of their second year of study, 13 percent of the entrants (77 individuals) had dropped out. By the beginning of their third year of study (Fall 2004), attrition was 26 percent for the enrolling cohort. Substantial differences in attrition

\footnotetext{
${ }^{11}$ There are 223 AUIT students among the 586 in the entering class. Among these, 63 percent attended economics Ph.D.-granting, 16 percent Top-50 liberal arts, 13 percent other public, and 8 percent other private undergraduate institutions. These percentages imply that our sample includes more students from economics Ph.D.-granting and fewer from other private undergraduate institutions than is represented by the SED data in Table 1 for Ph.D.s graduating in 1997-2003.
} 
emerge on the basis of type and location of undergraduate training. For example, after two full years in the Ph.D. programs, the 30 percent dropout rate for AUIT Ph.D.s was six percentage points higher than that of those trained overseas, a difference that is statistically significantly different at the 0.10 level. Moreover, there are substantial differences in attrition based on the type of undergraduate institution attended. Among the AUIT Ph.D. students, the lowest attrition (21 percent after two years) occurred among Ph.D. students who earned their undergraduate degrees from the nation's 50 most prestigious private liberal arts colleges (plus the six we added), and the highest attrition (50 percent after two years) occurred among the 30 Fall 2002 matriculants whose undergraduate degrees were awarded by public universities that do not offer a Ph.D. in economics (although only the latter group's attrition rate is significantly different from that of other Ph.D. students).

In their study of the match between the skills learned in graduate school and those used by economics Ph.D.s on the job, Stock and Hansen (2004, Table 2) report that among recent graduating cohorts of economics Ph.D.s, analytics (understanding and solving problems, making and analyzing logical arguments) and mathematics (constructing and analyzing proofs, manipulating mathematical abstractions) were consistently rated by graduates as the skills most important for success in their Ph.D. programs. In contrast, the largest fraction of graduates listed communication (speaking and writing effectively, quickly understanding spoken and written ideas of others, explaining ideas clearly) as the skill most important for success in their jobs.

The inclination to enter, and ability to succeed, in a Ph.D. program may depend on a student's innate quantitative and verbal skills. Those skills, in turn, may be related to the type of undergraduate college a person attended. To explore this possibility, in Table 7, we also report separately by type of undergraduate institution the mean verbal, analytical, and quantitative GRE 
scores for the 2002 entering Ph.D. class. If GRE analytical, quantitative, and verbal scores reflect aptitude in analytic, mathematic, and communication skills, the mix of aptitude among first-year Ph.D. students as reported in Table 7 presents a conundrum. On the one hand, firstyear Ph.D. students who did their undergraduate work at economics Ph.D.-granting institutions earned higher analytical GRE scores but lower quantitative GRE scores than other first-year students, while the opposite is true for students from foreign institutions where English is not the dominant language; they have the highest quantitative but the lowest analytical GRE scores among the first year class. In both cases, the GRE scores send mixed signals in terms of the students' mastery of the skills rated most important for success in graduate school. On the other hand, graduates of economics Ph.D.-granting institutions, those from top-50 liberal arts colleges, and those from foreign institutions where English is the dominant language earn higher verbal GRE scores than others, while students from foreign institutions where English is not the dominant language earn lower verbal GRE scores - suggesting that the graduates from these different types of institutions may face ease (or difficulty) in mastering the communication skills that their predecessors rate as highly important for success on the job. ${ }^{12}$

In Table 8 we present probit regression estimates of two-year attrition for the 572 members of the entering class for whom we have complete survey information. Unlike the raw means presented in Table 7, the regression controls for differences in demographic characteristics (age, sex, citizenship), school-related characteristics (whether the student held a

\footnotetext{
${ }^{12}$ Although not shown in the table, as another test of the belief that mathematical and quantitative abilities have become important predictors of success in graduate school, we also compared the GRE scores of the 12 Ph.D. students among the entering class of 2002 who attended one of the engineering schools listed in Figure 5 against those of the 220 first-year students who attended other U.S. undergraduate institutions. The mean quantitative and analytical GRE scores are higher (by 24 and 22 points, respectively) for those who attended engineering schools, but only the difference in the quantitative score comes close to statistical significance (p-value 0.13 ).
} 
prior advanced degree, an undergraduate major in economics, math, or a dual major in economics/math, and the years since the undergraduate degree was earned), whether the student indicated an interest in micro theory, macro theory, or econometrics (the core of the first-year curriculum, indicated by the variable theory interest) or in another specific field of economics on their economics Ph.D. program application, and GRE scores. The regression also includes firstyear financial aid variables, undergraduate institution characteristics, and indicators for particular graduate programs (i.e. binary variables representing the 24 institutions with ten or more students in the regression sample).

The regression estimates indicate that once other factors are controlled, none of the demographic or other school-related characteristics is related to attrition. The only exception is the verbal GRE score, but its impact is small, with a ten point increase being associated with only a .003 decrease in the probability of dropout. ${ }^{13}$ Not surprisingly, those who have no financial support are more likely to dropout in the first two years of graduate study, being 21 percentage points more likely to do so than their counterparts with teaching assistantships. Among the undergraduate institution groups, only other foreign is significantly associated with dropout, with those students having about a .2 lower probability of dropout relative to their counterparts from economics Ph.D.-granting institutions.

Finally, to examine variations in the time required to earn a Ph.D. in economics, we estimated a hazard model based on a Weibull distribution for 302 economists who earned their Ph.D.s between July 1, 2001 and June 30, 2002, and who answered all pertinent questions on a survey administered in early 2003 as part of a larger study of the labor market for new Ph.D.s (Siegfried and Stock, 2004). The survey included at least partial information for 61 percent of

\footnotetext{
${ }^{13}$ When we estimate the attrition model without GRE scores included, the estimated coefficients on the undergraduate institution variables do not change appreciably. Assuming that GRE scores are good measure of student ability, this implies that the institution type variables measure something beyond that.
} 
those who earned economics Ph.D.s in the U.S. in 2001-02 and includes Ph.D. graduates from 101 universities. Non-U.S. citizens and graduates holding permanent jobs are under represented among survey respondents, but the sample is otherwise representative of the graduating class of 2001-02 (see Siegfried and Stock, 2004 for a more thorough discussion of the sample and its representativeness).

Included in the model as explanatory variables for time-to-degree are indicators for particular graduate programs (i.e. binary variables representing the six institutions with ten or more graduates in the regression sample), type of financial support, type of dissertation (traditional treatise or set of essays), field of specialization, socio-demographic and educational background characteristics, and the type of undergraduate institution attended. The variable means and coefficient estimates from the regression are reported in Table $9 .{ }^{14}$

We have discussed the relationships between demographic and graduate program characteristics and time-to-degree elsewhere (e.g., Siegfried and Stock, 2004, p. 277; Stock and Siegfried, 2006). Here we elaborate on relationships between type of undergraduate institution and time-to-degree. The group of binary variables indicating various types of undergraduate institutions attended by the 302 Ph.D. economists in our sample explains a statistically significant additional amount of the variation in the time it took them to earn their degrees (the pvalue in a test of their joint significance is 0.000 ). There are also economically meaningful differences in time-to-degree among those who attended different types of undergraduate institutions. Those who graduated from a selective private liberal arts college finished about eight months faster than the benchmark group whose undergraduate study was at a university that also offers a Ph.D. in economics. Those who earned undergraduate degrees from foreign

\footnotetext{
${ }^{14}$ The 18 graduates whose time-to-degree was more than two standard deviations above the mean of 5.6 years were excluded from the analysis.
} 
predominantly English speaking universities finished eleven months faster, and those who earned undergraduate degrees from other foreign universities finished about five months faster than the benchmark. Although not significantly different from the benchmark, the slowest group is those from public universities in the U.S. that do not offer a Ph.D. in economics, the same group with the worst attrition record.

Graduates who completed undergraduate study at selective American liberal arts colleges, or whose undergraduate training was in Britain, Canada, Ireland, Australia, or New Zealand, earned a Ph.D. in economics sufficiently faster than the large group of undergraduates from American Ph.D. granting universities so as to save almost a full academic year. The savings from an academic year could be viewed as a full year's opportunity cost to graduates, and/or a year of financial aid from the Ph.D. department. Applicants from Swarthmore, Williams, or Carleton, therefore, might be viewed appropriately as likely "less expensive” Ph.D. students than those with a bachelor's degree from Harvard, Berkeley, or Stanford. Accordingly, Ph.D. program admissions committees might reasonably dip further into the credentials pool for those with an undergraduate degree from a selective liberal arts college. On the other hand, expanding the pool of selective liberal arts college graduates attracted into Ph.D. study, which such a policy could induce, may add prospects whose expected time-to-degree differs from the expected length of Ph.D. study of existing matriculants.

\section{Conclusion}

This paper documents the types of colleges and universities attended by those who earned doctorates in economics from American universities from 1966 to 2003. The total number of new economics Ph.D.s awarded to U.S. citizens has declined precipitously since 1972. Among 
those who earned an undergraduate degree in the U.S., however, the composition of undergraduate alma maters of the doctorates has been relatively stable, with about 55 percent of those earning a Ph.D. in economics each year holding a bachelors degree from a university that offers a Ph.D. in economics, and a little more than 10 percent holding a bachelors degree from a selective liberal arts college.

Currently, 18 of the 25 American undergraduate institutions that send the largest percentage of their graduating class on to earn a Ph.D. in economics are private liberal arts colleges. In addition, graduates of the top liberal arts colleges have the highest mean verbal GRE scores among the 2002 first-year class of economics Ph.D. students, and among recent cohorts of economics Ph.D.s, liberal arts college graduates completed their degrees in substantially less time than all other Ph.D. students except those from Britain, Canada, Ireland, Australia, and New Zealand.

Worldwide, Seoul National University in Korea is the leading incubator of future U.S. economics Ph.D.s, generating an average of 27 eventual economics Ph.D.s per year during the period 1997-2002. Among American institutions, Harvard tops the list of undergraduate institutions attended by eventual Ph.D.s in economics, but Swarthmore College and Illinois Wesleyan, respectively, are the top generators of eventual economics Ph.D.s. after controlling for institution and economics program size. 


\section{Figure 1}

Number of American Undergraduate Institutions Generating Eventual Ph.D.s and Number of Ph.D.s Generated

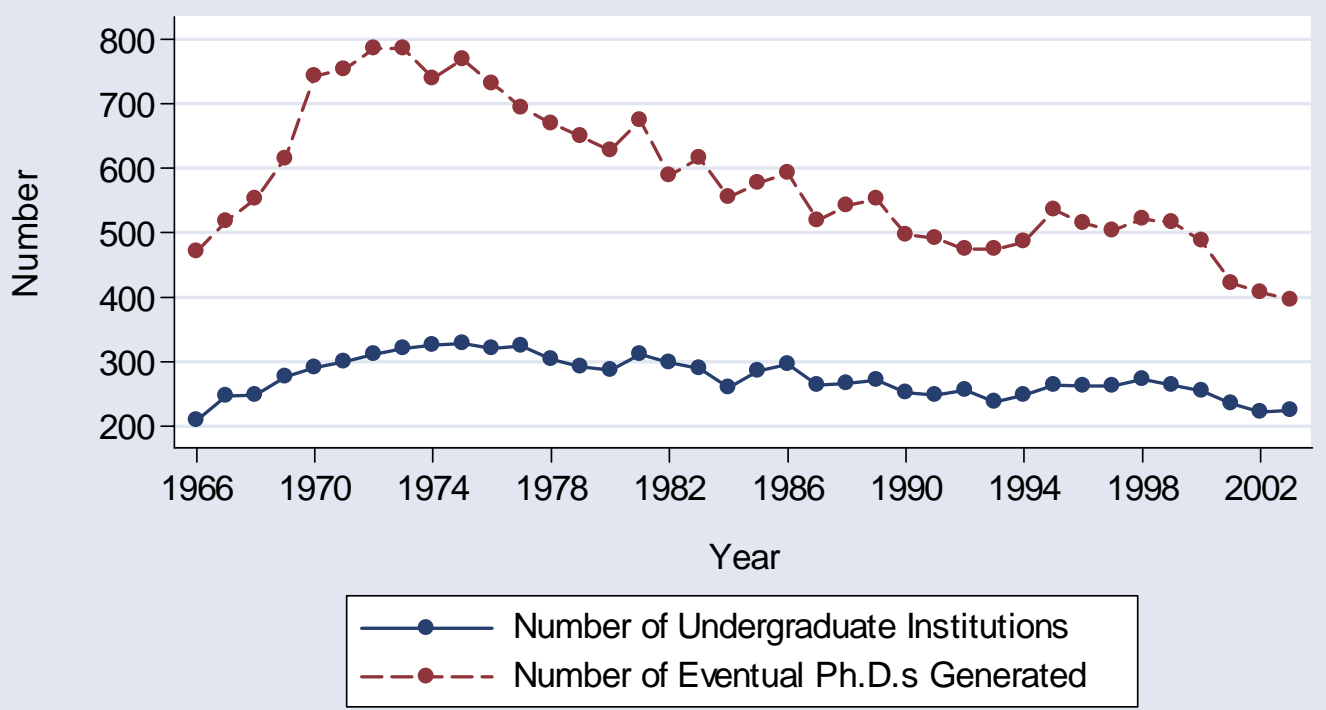

Source: Authors' calculations based on the Survey of Earned Doctorates.

\section{Figure 2}

Percent of Economics Ph.D.s Generated by Type of Undergraduate Institution

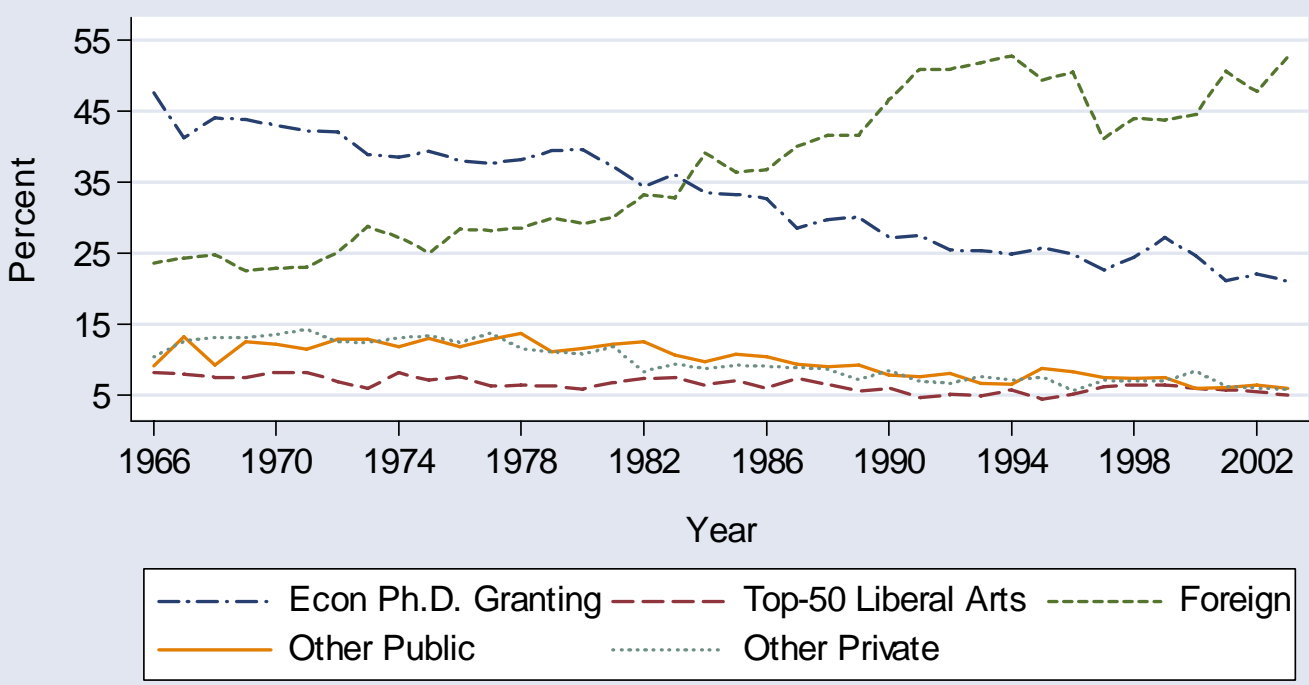

Source: Authors' calculations based on the Survey of Earned Doctorates. Total percentages do not sum to 100 because a small percentage of Economics Ph.D.s' undergraduate institutions are not classified. 


\section{Figure 3}

Number of Ph.D.s Generated per Undergraduate Institution

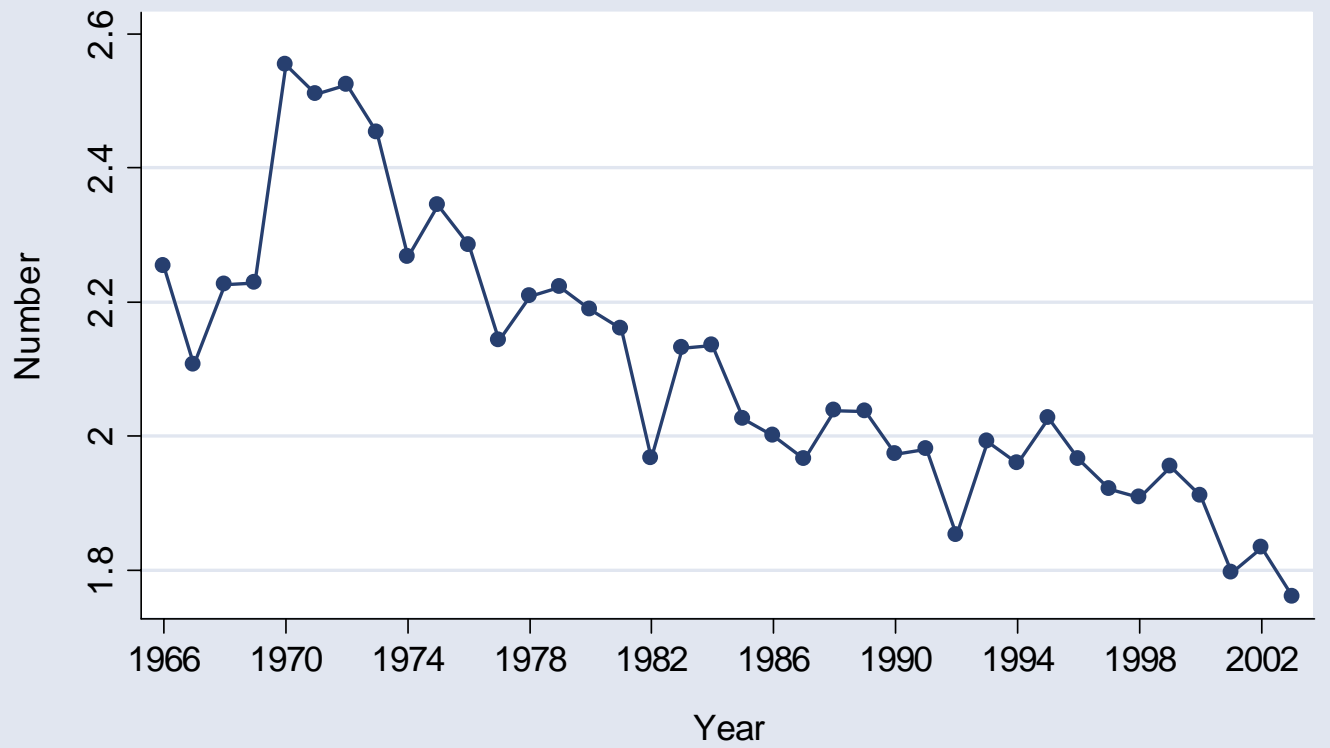

Source: Authors' calculations based on the Survey of Earned Doctorates.

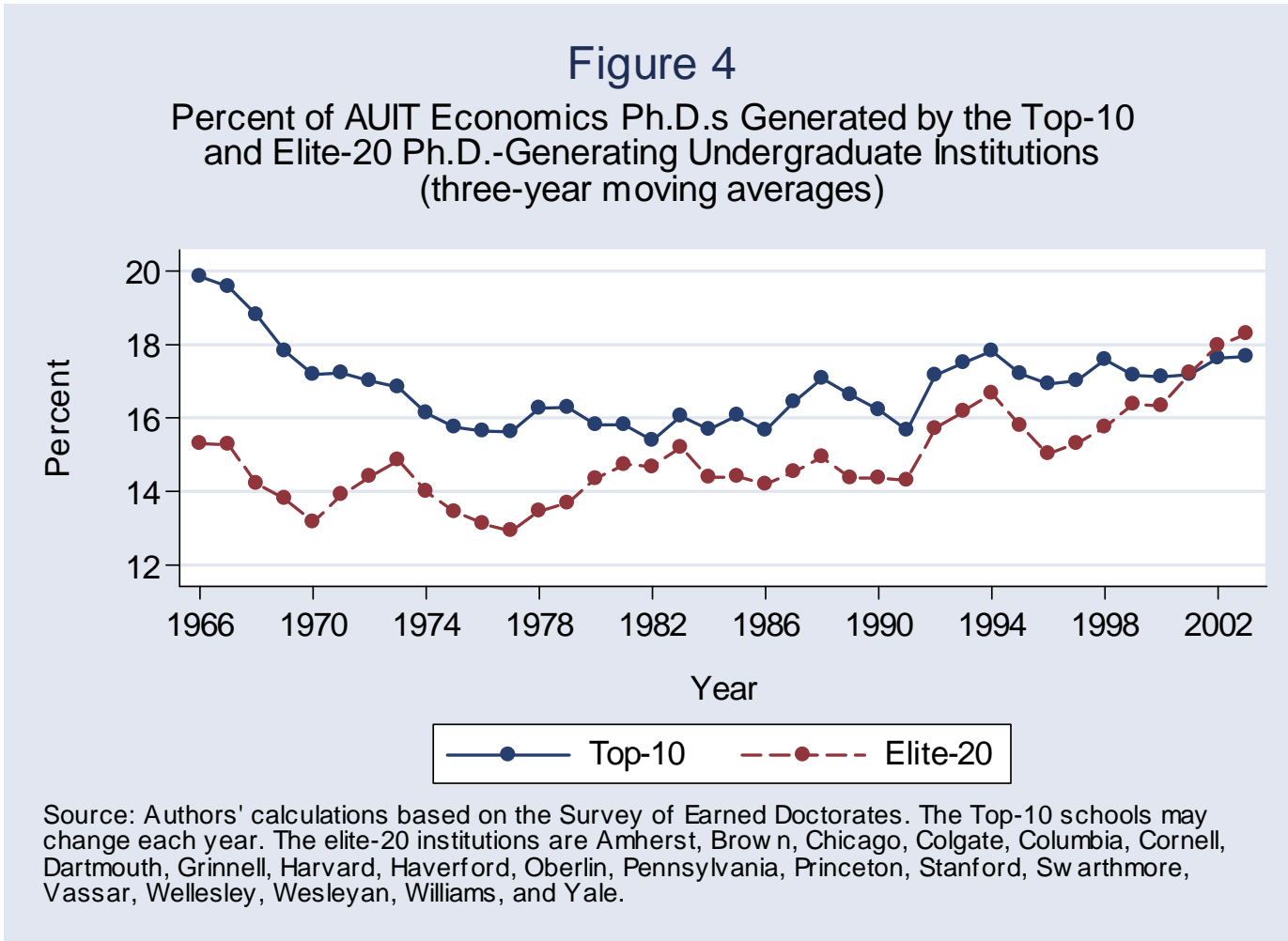




\section{Figure 5}

Percent of AUIT Economics Ph.D.s Generated by Engineering Schools (three-year moving averages)

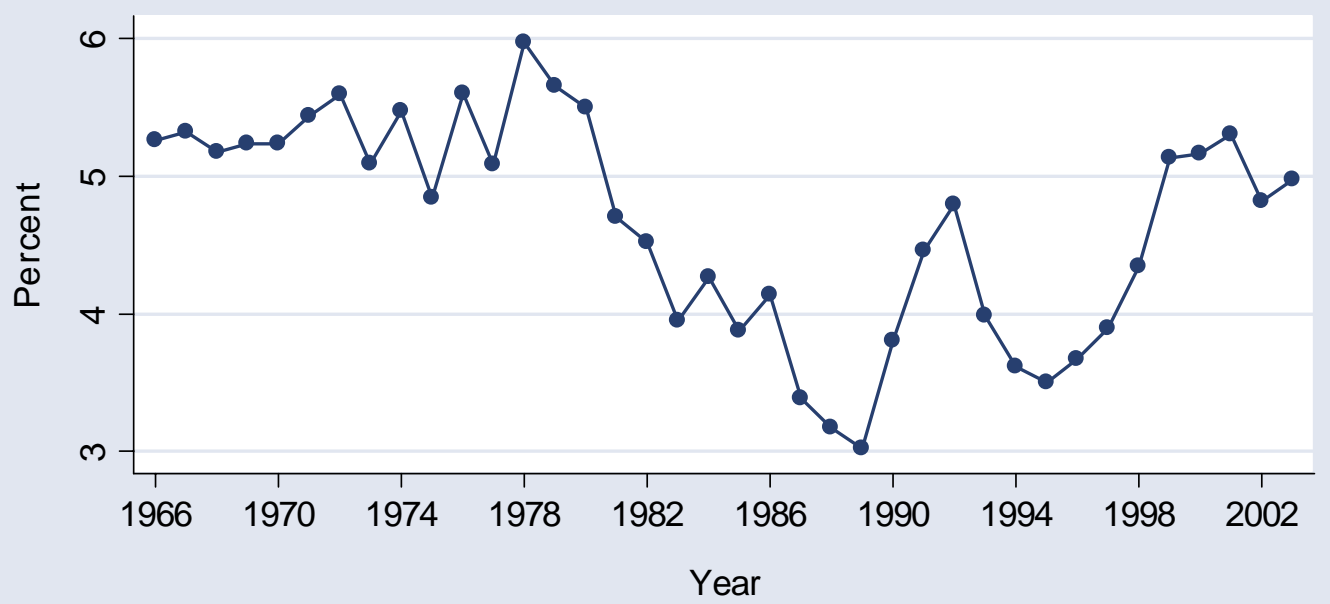

Source: Authors' calculations based on the Survey of Earned Doctorates.

The Engineering schools are Cal Poly-San Luis Obispo, Cal Tech, Carnegie Mellon, Case Western Reserve, Cooper Union, Georgia Tech, Harvey Mudd College, Illinois Tech, Michigan Tech, MIT, Purdue University, Rensselaer, Rice, Rose Institute of Technology, Stevens Institute of Technology, Texas A \& M, U.S. Air Force, Military, or Naval Academies, and Virginia Tech. 
Table 1: Shares of AUIT Ph.D.s generated, by Institution Type

\begin{tabular}{lcccc}
\hline \hline & \multicolumn{4}{c}{ Period } \\
Institution Type & 1970 & 1980 & 1990 & 2000 \\
\hline Econ Ph.D. Granting & 0.56 & 0.56 & 0.56 & 0.55 \\
Top-50 Liberal Arts & 0.10 & 0.10 & 0.11 & 0.14 \\
Other Public & 0.16 & 0.18 & 0.17 & 0.16 \\
Other Private & 0.18 & 0.16 & 0.16 & 0.16 \\
\hline
\end{tabular}

AUIT = American undergraduate institution trained. Cells present the number of Ph.D.s generated by each institution type during the period divided by the total number of Ph.D.s generated by all four types of institutions during the period. The periods are defined as: $1970=1967-1973,1980=1977-1983,1990=1987-$ 1993, $2000=1997-2003$. 
Table 2: Top Worldwide Sources of Eventual Economics Ph.D.s, 1997-2002

\begin{tabular}{|c|c|c|}
\hline University Name & Country & $\begin{array}{c}\text { Number of } \\
\text { Eventual Ph.D. } \\
\text { Economists } \\
\text { Generated during } \\
\text { 1997-2002 }\end{array}$ \\
\hline Seoul National University & Korea & 162 \\
\hline Harvard University & USA & 74 \\
\hline National Taiwan University & Taiwan & 63 \\
\hline University of Delhi & India & 61 \\
\hline University of California, Berkeley & USA & 54 \\
\hline Universita Commerciale "Luigi Bocconi" & Italy & 45 \\
\hline Yonsei University & Korea & 44 \\
\hline Stanford University & USA & 40 \\
\hline Beijing University & China & 36 \\
\hline Cornell University & USA & 33 \\
\hline Korea University & Korea & 33 \\
\hline Fudan University & China & 32 \\
\hline Tokyo University & Japan & 32 \\
\hline University of Michigan & USA & 32 \\
\hline Yale University & USA & 32 \\
\hline MIT & USA & 30 \\
\hline Middle East Technical University & Turkey & 30 \\
\hline Princeton University & USA & 30 \\
\hline University of Wisconsin, Madison & USA & 30 \\
\hline Swarthmore College & USA & 29 \\
\hline University of Pennsylvania & USA & 28 \\
\hline College of William and Mary & USA & 26 \\
\hline Es. Superior de Comercio "Carloss Pellegrini" & Argentina & 26 \\
\hline University of Calcutta & India & 26 \\
\hline Instituto Tecnológico Autónoma de México & Mexico & 24 \\
\hline University of Maryland & USA & 24 \\
\hline
\end{tabular}

Source: Survey of Earned Doctorates. The column presents the number of economists who earned their Ph.D. during 1997-2002 $(\mathrm{N}=5,133)$ and who listed the school as their undergraduate university. 


\begin{tabular}{lc}
\hline \hline & \\
& $\begin{array}{c}\text { Number of Eventual } \\
\text { Ph.D.s Generated } \\
\text { during 1997-2003 }\end{array}$ \\
University Name & 86 \\
\hline Harvard University & 69 \\
University of California-Berkeley & 51 \\
Cornell University & 51 \\
Stanford University & 46 \\
University of Wisconsin-Madison & 40 \\
University of Michigan & 39 \\
Swarthmore College & 39 \\
Yale University & 37 \\
Princeton University & 35 \\
MIT & 34 \\
University of Pennsylvania & 30 \\
University of Maryland & 28 \\
Brigham Young University & 28 \\
University of Virginia & 27 \\
College of William and Mary & 27 \\
Columbia University & 27 \\
Texas A\&M University & 26 \\
University of Illinois & 26 \\
University of Texas & 25 \\
University of California-Davis & 25 \\
University of Massachusetts & 25 \\
Williams College & 24 \\
UCLA & 23 \\
Duke University & 23 \\
Miami University & 23 \\
Michigan State University & \\
Northwestern University & 23 \\
\hline Sore: Ans & 39 \\
\hline
\end{tabular}

Source: Authors' calcualtions based on the Survey of Earned Doctorates. 
Table 4: Institution Size Normalized Top American Sources of Eventual Economics

Ph.D.s, 1997-2003

\begin{tabular}{|c|c|c|c|}
\hline Institution Name & $\begin{array}{c}\text { Number of } \\
\text { Eventual } \\
\text { Ph.D.s } \\
\text { Generated } \\
\text { 1997-2003 } \\
\end{array}$ & $\begin{array}{c}\text { Number of } \\
\text { Undergraduate } \\
\text { Degrees } \\
\text { Awarded 1987- } \\
1993 \\
\end{array}$ & $\begin{array}{c}\text { Eventual Ph.D.s } \\
\text { generated per } \\
1000 \\
\text { undergraduate } \\
\text { degrees awarded }\end{array}$ \\
\hline $\begin{array}{l}\text { Swarthmore College } \\
\text {. }\end{array}$ & 39 & 2579 & 15.12 \\
\hline Agnes Scott College & 7 & 771 & 9.08 \\
\hline Grinnell College & 20 & 2212 & 9.04 \\
\hline Carleton College & 22 & 3127 & 7.04 \\
\hline Williams College & 25 & 3593 & 6.96 \\
\hline Harvard University & 86 & 12500 & 6.88 \\
\hline Macalester College & 17 & 2620 & 6.49 \\
\hline Princeton University & 37 & 7742 & 4.78 \\
\hline Trinity University & 16 & 3515 & 4.55 \\
\hline MIT & 35 & 7849 & 4.46 \\
\hline Stanford University & 51 & 11597 & 4.40 \\
\hline Yale University & 39 & 9115 & 4.28 \\
\hline Wabash College & 5 & 1274 & 3.92 \\
\hline Bowdoin College & 10 & 2557 & 3.91 \\
\hline University of Chicago & 21 & 5567 & 3.77 \\
\hline Oberlin College & 19 & 5038 & 3.77 \\
\hline Wellesley College & 15 & 4099 & 3.66 \\
\hline Earlham College & 6 & 1700 & 3.53 \\
\hline Kalamazoo College & 6 & 1726 & 3.48 \\
\hline Beloit College & 5 & 1531 & 3.27 \\
\hline Pomona College & 8 & 2491 & 3.21 \\
\hline Illinois Wesleyan University & 8 & 2529 & 3.16 \\
\hline College of William and Mary & 27 & 8737 & 3.09 \\
\hline Amherst College & 9 & 2917 & 3.09 \\
\hline Columbia University & 27 & 8932 & 3.02 \\
\hline Rice University & 13 & 4434 & 2.93 \\
\hline
\end{tabular}

Source: Authors' calculations based on IPEDS completions data available on WebCASPAR. Calculations are limited to schools that produced anaverage of at least $100 \mathrm{BA} / \mathrm{BS}$ degrees and an average of at least 5 economics BA/BS degrees per year during 1987-1993, and who produced at least 2 Ph.D.s during the period 1997-2003. 
Table 5: Economics Program-Size Normalized Top American Sources of Eventual Economics Ph.D.s, 1997-2003

\begin{tabular}{|c|c|c|c|}
\hline Institution Name & $\begin{array}{c}\text { Number of } \\
\text { Eventual } \\
\text { Ph.D.s } \\
\text { Generated } \\
\text { 1997-2003 } \\
\end{array}$ & $\begin{array}{c}\text { Number of } \\
\text { Economics } \\
\text { Undergraduate } \\
\text { Degrees } \\
\text { Awarded 1987- } \\
1993 \\
\end{array}$ & $\begin{array}{c}\text { Eventual Ph.D.s } \\
\text { generated per } \\
\text { economics } \\
\text { undergraduate } \\
\text { degree awarded }\end{array}$ \\
\hline Illinois Wesleyan University & 8 & 42 & 0.19 \\
\hline Swarthmore College & 39 & 292 & 0.13 \\
\hline Bemidji State University (MN) & 5 & 44 & 0.11 \\
\hline Earlham College & 6 & 56 & 0.11 \\
\hline Reed College & 5 & 47 & 0.11 \\
\hline Grinnell College & 20 & 191 & 0.10 \\
\hline Wheaton College (Wheaton, IL) & 7 & 68 & 0.10 \\
\hline University of Memphis & 6 & 59 & 0.10 \\
\hline Agnes Scott College & 7 & 75 & 0.09 \\
\hline University of Alabama & 5 & 55 & 0.09 \\
\hline Concordia College & 5 & 58 & 0.09 \\
\hline Oberlin College & 19 & 222 & 0.09 \\
\hline MIT & 35 & 413 & 0.08 \\
\hline Carleton College & 22 & 264 & 0.08 \\
\hline Trinity University & 16 & 195 & 0.08 \\
\hline Hood College & 3 & 39 & 0.08 \\
\hline Loyola University of Chicago & 3 & 46 & 0.07 \\
\hline Miami University & 23 & 355 & 0.06 \\
\hline Ithaca College & 5 & 78 & 0.06 \\
\hline Ohio Wesleyan University & 5 & 78 & 0.06 \\
\hline University of Miami & 5 & 79 & 0.06 \\
\hline Macalester College & 17 & 272 & 0.06 \\
\hline Western Kentucky University & 6 & 98 & 0.06 \\
\hline Rochester Institute of Technology & 3 & 50 & 0.06 \\
\hline Frostburg State University & 4 & 67 & 0.06 \\
\hline La Salle University & 5 & 85 & 0.06 \\
\hline College of Charleston & 3 & 54 & 0.06 \\
\hline
\end{tabular}

Source: Authors' calculations based on IPEDS completions data available on WebCASPAR.

Calculations are limited to schools that produced an average of at least $100 \mathrm{BA} / \mathrm{BS}$ degrees and an average of at least 5 economics BA/BS degrees per year during 1987-1993, and who produced at least 2 Ph.D.s during the period 1997-2003. 
Table 6: AUIT Ph.D.s generated, Normalized by Institution Size and Economics Program Size

\begin{tabular}{|c|c|c|c|c|c|}
\hline & 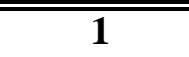 & 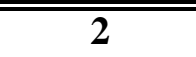 & 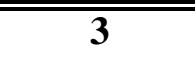 & 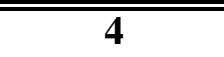 & 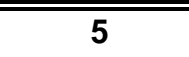 \\
\hline Institution Type & $\begin{array}{c}\text { Number of } \\
\text { Ph.D.s } \\
\text { generated } \\
\text { 1997-2003 }\end{array}$ & $\begin{array}{c}\text { Number of } \\
\text { BA/BS } \\
\text { graduates } \\
\text { generated } \\
\text { 1987-1993 }\end{array}$ & $\begin{array}{c}\text { Number of } \\
\text { Economics } \\
\text { BA/BS } \\
\text { graduates } \\
\text { generated } \\
\text { 1987-1993 }\end{array}$ & $\begin{array}{c}\text { Ph.D.s per } \\
1000 \text { BA/BS } \\
\text { graduates }\end{array}$ & $\begin{array}{c}\text { Ph.D.s per } \\
1000 \\
\text { Economics } \\
\text { BA/BS } \\
\text { graduates }\end{array}$ \\
\hline Econ Ph.D. Granting & 1,752 & $2,298,218$ & 113,800 & 0.76 & 49.52 \\
\hline Top-50 Liberal Arts & 427 & 173,465 & 14,889 & 2.46 & 85.83 \\
\hline Other Public & 257 & 822,377 & 17,924 & 0.31 & 21.80 \\
\hline Other Private & 265 & 304,806 & 10,539 & 0.87 & 34.58 \\
\hline
\end{tabular}

Source: Authors' calculations based on SED and IPEDS completions data available on WebCASPAR.

Table 7: Characteristics of Ph.D. Students, by Institution Type

\begin{tabular}{|c|c|c|c|c|c|c|c|}
\hline & 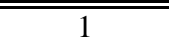 & 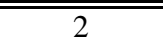 & 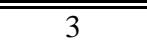 & 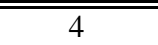 & 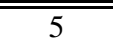 & 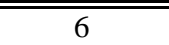 & 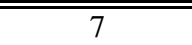 \\
\hline Institution Type & $\begin{array}{c}\text { Number of } \\
\text { First Year } \\
\text { Students } \\
\text { Generated }\end{array}$ & $\begin{array}{c}\text { Share of } \\
\text { First Year } \\
\text { Students }\end{array}$ & $\begin{array}{l}\text { First year } \\
\text { dropout } \\
\text { rate }\end{array}$ & $\begin{array}{l}\text { Two-year } \\
\text { dropout } \\
\text { rate }\end{array}$ & $\begin{array}{c}\text { Mean } \\
\text { Verbal } \\
\text { GRE }\end{array}$ & $\begin{array}{c}\text { Mean } \\
\text { Analytical } \\
\text { GRE }\end{array}$ & $\begin{array}{c}\text { Mean } \\
\text { Quantitative } \\
\text { GRE }\end{array}$ \\
\hline Econ Ph.D. Granting & 142 & 0.24 & $0.17^{>a}$ & 0.29 & $598^{>a}$ & $732^{>}$ & $760^{<}$ \\
\hline Top-50 Liberal Arts & 33 & 0.06 & 0.15 & 0.21 & $623^{>}$ & 729 & 765 \\
\hline Other Public & 30 & 0.05 & $0.30^{>}$ & $0.50^{>}$ & 585 & 721 & $743^{<}$ \\
\hline Other Private & 18 & 0.03 & 0.06 & 0.28 & 592 & 721 & $751^{<}$ \\
\hline $\begin{array}{l}\text { Britian, Canada, Ireland, } \\
\text { Australia, New Zealand }\end{array}$ & 27 & 0.05 & 0.07 & $0.15^{<}$ & $606^{>}$ & 738 & 780 \\
\hline Other Foreign & 336 & 0.57 & $0.11^{<}$ & 0.25 & $534^{<}$ & $716^{<}$ & $781^{>}$ \\
\hline All AUIT & 223 & 0.38 & $0.17^{>}$ & $0.30^{>}$ & $599^{>}$ & $729^{>}$ & $757^{<}$ \\
\hline All Foreign & 363 & 0.62 & $0.10^{<}$ & $0.24^{<}$ & $539^{<}$ & $718^{<}$ & $781^{>}$ \\
\hline Total & 586 & 1.00 & 0.13 & 0.26 & 562 & 722 & 772 \\
\hline
\end{tabular}

a ">" ("<") = value is significantly higher (lower) than the mean for the rest of the sample at the 0.10 level (one-tailed tests). The number of observations for the GRE scores is lower than for the whole sample because GRE score information was not available for 12 of the students. 
Table 8: Attrition from Economics Ph.D. Programs, Probit Model

\begin{tabular}{|c|c|c|c|}
\hline Variable & $\begin{array}{c}1 \\
\text { mean }\end{array}$ & $\begin{array}{c}2 \\
\mathbf{d Y} / \mathbf{d X}\end{array}$ & $\begin{array}{c}3 \\
\text { z-ratio }\end{array}$ \\
\hline Dropout* & 0.26 & - & - \\
\hline \multicolumn{4}{|l|}{ Demographics } \\
\hline Age at matriculation & 25.44 & -0.004 & -0.34 \\
\hline Female* & 0.35 & 0.075 & 1.72 \\
\hline U.S. Citizen* & 0.33 & -0.115 & -1.65 \\
\hline Prior advanced degree* & 0.45 & -0.002 & -0.04 \\
\hline Prior BA/BS economics* & 0.70 & -0.051 & -1.05 \\
\hline Prior BA/BS economics/math* & 0.06 & -0.130 & -1.70 \\
\hline Prior BA/BS math* & 0.03 & -0.112 & -1.16 \\
\hline Years since BA/BS degree & 2.69 & -0.010 & -0.81 \\
\hline Theory interest* & 0.34 & -0.019 & -0.44 \\
\hline No interest specified* & 0.25 & 0.014 & 0.24 \\
\hline GRE analytical score $\left(\times 10^{-1}\right)$ & 72.28 & -0.002 & -0.97 \\
\hline GRE verbal score $\left(\mathrm{x} 10^{-1}\right)$ & 56.26 & -0.003 & -2.07 \\
\hline GRE quantitative score $\left(\mathrm{x} 10^{-1}\right)$ & 77.20 & -0.006 & -1.16 \\
\hline \multicolumn{4}{|c|}{ Primary type of financial assistance } \\
\hline Teaching assistant* & 0.28 & - & - \\
\hline Research assistant* & 0.05 & -0.107 & -0.77 \\
\hline Fellowship* & 0.47 & 0.104 & 1.84 \\
\hline No support* & 0.20 & 0.214 & 3.16 \\
\hline \multicolumn{4}{|l|}{ Type of undergraduate institution } \\
\hline Economics Ph.D. Granting* & 0.24 & - & - \\
\hline Top-50 Liberal Arts* & 0.06 & -0.093 & -1.17 \\
\hline Other Public* & 0.05 & 0.165 & 1.75 \\
\hline Other Private* & 0.03 & -0.028 & -0.28 \\
\hline \multicolumn{4}{|c|}{ Britian, Canada, Ireland, Australia, New } \\
\hline Zealand* & 0.05 & -0.163 & -1.77 \\
\hline Other Foreign* & 0.57 & -0.187 & -2.31 \\
\hline
\end{tabular}

Notes: $\mathrm{N}=572 .{ }^{*}$ indicates binary variables. Coefficients in bold are statistically significant at the 0.10 level (two-tailed tests). Regression also includes a constant and binary controls for the $24 \mathrm{Ph}$.D. programs with 10 or more graduates in the regression sample. 
Table 9: Time-to-Degree for the Economics Ph.D. Class of 2001-02, Duration Model

\begin{tabular}{|c|c|c|c|c|}
\hline Variable & mean & $\begin{array}{c}\text { Estimated } \\
\text { exponentiated } \\
\text { accelerated } \\
\text { failure time } \\
\text { coefficients } \\
\end{array}$ & z-ratio & $\begin{array}{c}4 \\
\text { Predicted } \\
\text { change in } \\
\text { Time to } \\
\text { degree for } \\
\text { statistically } \\
\text { significant } \\
\text { coefficients } \\
\text { (in months) }\end{array}$ \\
\hline Time to Degree (years) & 5.60 & - & - & - \\
\hline \multicolumn{5}{|l|}{ Demographics } \\
\hline Age at matriculation & 26.32 & 0.996 & -1.94 & -0.3 \\
\hline Female* & 0.28 & 0.994 & -0.22 & \\
\hline Married at matriculation* & 0.23 & 0.993 & -0.16 & \\
\hline U.S. Citizen* & 0.54 & 0.996 & -0.09 & \\
\hline Had child at matriculation* & 0.10 & 0.967 & -0.51 & \\
\hline Female*had child at matriculation* & 0.02 & 0.991 & -0.09 & \\
\hline White* & 0.73 & 1.011 & 0.32 & \\
\hline Prior master's degree* & 0.40 & 0.930 & -2.61 & -4.7 \\
\hline Prior economics degree* & 0.83 & 1.031 & 0.86 & \\
\hline \multicolumn{5}{|l|}{ Primary type of financial assistance } \\
\hline Teaching assistant* & 0.31 & - & - & - \\
\hline Research assistant* & 0.08 & 0.923 & -1.55 & \\
\hline Fellowship* & 0.08 & 0.868 & -3.42 & -8.9 \\
\hline Government support* & 0.04 & 0.870 & -1.84 & \\
\hline Mixed support* & 0.45 & 0.929 & -2.30 & -4.8 \\
\hline No support* & 0.04 & 1.110 & 1.54 & \\
\hline Dissertation set of essays* & 0.61 & 0.908 & -3.35 & -6.2 \\
\hline \multicolumn{5}{|l|}{ Type of undergraduate institution } \\
\hline Economics Ph.D. Granting* & 0.31 & - & - & - \\
\hline Top-50 Liberal Arts* & 0.11 & 0.875 & -3.26 & -8.4 \\
\hline Other Public* & 0.08 & 1.092 & 1.47 & \\
\hline $\begin{array}{l}\text { Other Private* } \\
\text { Britian, Canada, Ireland, Australia, }\end{array}$ & 0.08 & 0.912 & -1.54 & \\
\hline New Zealand* & 0.05 & 0.844 & -2.95 & -10.5 \\
\hline Other Foreign* & 0.37 & 0.922 & -2.01 & -5.2 \\
\hline
\end{tabular}

Notes: $\mathrm{N}=302 .{ }^{*}$ indicates binary variables. Regression also includes a constant, binary controls for Ph.D. programs with 10 or more graduates in the regression sample (programs are Chicago, Harvard, MIT, NYU, Maryland, and Berkeley), and binary controls for field of specialization. 


\section{References}

Brown, Heath, and Maria Doulis. 2005. Findings from 2005 CGS International Graduate Admissions Survey I. (Council of Graduate Schools: Washington, D.C.).

Finegan, T. Aldrich, John J. Siegfried and Wendy A. Stock. 2006. "Matriculation into U.S. Economics Ph.D. Programs: How Many Accepted Americans do not Enroll?” American Economic Review (May) 96(2): xxx - yyy.

Freeman, Richard B., Emily Jin and Chia-Yu Shen. 2004. "Where Do New US-Trained ScienceEngineering PhDs Come From?” Unpublished manuscript, National Bureau of Economic Research, Working Paper 10554, June 2004.

Goldberger, Marvin, Brendan Maher, and Pamela Flattau, eds. $1995 . \quad$ Research-Doctorate Programs in the United States: Continuity and Change. Washington, DC: National Academy Press.

Groen, Jeffrey A., and Michael J. Rizzo. 2004. "The Changing Composition of AmericanCitizen PhDs.” Unpublished manuscript, Cornell Higher Education Research Institute, Cornell University, March 9, 2004.

Lemke, Robert J., Todor L. Barzev, Detelina N. Filipova and Veska I. Suleva. 2005. "Economics BA's and Ph.D.'s from Liberal Arts Colleges: Do Degree Requirements or Faculty Scholarship Matter?” Unpublished manuscript, Lake Forest College, January 25, 2005.

Laband, D. N., and B. F. Lentz. 1985. The roots of success: why children follow in their parents' occupational footsteps. New York, Praeger.

McGoldrick, KimMarie. 2006. The senior experience for economics majors: results from a survey of departmental practices.” Unpublished manuscript, University of Richmond.

Siegfried, John J. 2000. "How Many College Students are Exposed to Economics?” Journal of Economic Education (Spring) 31(2): 202-204.

Siegfried, John J. and David K. Round. 2001. "International Trends in Undergraduate Economics Degrees.” Journal of Economic Education (Summer) 32(3): 203-218.

Siegfried, John, and Malcolm Getz. 2006. "Where do the children of professors attend college?” Economics of Education Review. 25: 201-210.

Siegfried, John J. and Wendy A. Stock. 1999. "The Labor Market for New Ph.D. Economists.” Journal of Economic Perspectives (Summer) 13(3): 115-134.

Siegfried, John J. and Wendy A. Stock. 2001. "So You Want to Earn a Ph.D. in Economics: How Long Do You Think It Will Take?” Journal of Human Resources (Spring) 36(2): 364-378. 
Siegfried, John J., and Wendy A. Stock. 2004. "The Labor Market for New Ph.D. Economists in 2002.” American Economic Review (May) 94(2): 272-285.

Siegfried, John J. and Wendy A. Stock. 2006. "Where Are They Now? Tracking the Ph.D. Class of 1997." forthcoming, Southern Economic Journal.

Stock, Wendy A., Richard Alston, and Martin Milkman. 2000. "The Academic Labor Market for Economists - 1995-96." Atlantic Economic Journal (June) 28(2): 164-185.

Stock, Wendy A. and Richard Alston. 2000. "The Effect of Graduate-Program Rank on Success in the Job Market." Journal of Economic Education (Fall) 31(4): 389-401.

Stock, Wendy A. and John J. Siegfried. 2001. "So You Want to Earn a Ph.D. in Economics: How Much Do You Think You Will Make?" Economic Inquiry (April) 39(2): 320-335.

Stock, Wendy A. and W. Lee Hansen. 2004. "Ph.D. Program Learning and Job Demands: How close is the Match?” American Economic Review Papers and Proceedings (May) 94(2): 266271.

Stock, Wendy A., T. Aldrich Finegan, and John J. Siegfried. 2006. “Attrition in Economics Ph.D. Programs.” American Economic Review (May) 96(2): xxx-yyy.

Stock, Wendy A. and John J. Siegfried. 2006. "Time-to-Degree for the Economics Ph.D. Class of 2001-02.” American Economic Review (May) 96(2): xxx - yyy.

Tidball, M. Elizabeth. 1986. "Baccalaureate Origins of Recent Natural Science Doctorates.” The Journal of Higher Education (November-December) 57:6, pp. 606-620.

Zhang, Liang. 2004. "Advance to Graduate Education: The Effect of College Quality and Undergraduate Majors,” Unpublished manuscript, Cornell University, School of Industrial and Labor Relations, June 2004. 